\title{
原 著少数穴の針効果
}

第 1 報 Thermal Video System からみた腹部瘀血証(小腹急結)に対する針効果

今西義則* 赤丸敏行 有地滋

要旨 針の遠隔効果を証明するために $l-\mathrm{Liv}^{-8}$ に針を刺し，そのまま 置針して左下腹部瘀血証部の皮膚温を皮虐温度計とThermal Video System で測定した。左下腹部瘀血証部の皮膚温は他の部より低温で あったのが上昇した。健常者に同様のことを行っても変化はみられな かった。

左下腹部瘀血証のある場合は $l-\mathrm{Liv}-8$ は握痛が認められた。健常者 には握痛は認められなかった。

異常のある経穴に針をすると異常のある特定の遠隔部に影響するこ とが判明した。

針効果は異常のある部にただ一穴で有効である。

\section{I はじめに}

針は2000年以前から疾病の治療に用いられてお $\eta ，$ 本治法と標治法がある。

針の作用は間葉系代謝伝達作用ともいうべき， ホメオスターティックな作用であると有地は述べ だ，が刺置針部位から遠隔部位の変動を客観的に 証明するため，腹部瘀血証部〔小腹急結（以下同 じ)」の皮䖉温の変化を熱電対式皮虚温度計(以下 皮膚温度計と略す) と Thermal Video System （以下TVSと略す）で測定した。

\section{II 実験方法}

1）対象：左下腹部に腹部瘀血証を認め, $l$ - Liv -8に圧痛を認めた患者 18 名〔心身症 8 名(男 1 , 女 7 ), 慢性肝炎 3 名 (男 1 , 女 2 ), 動脉硬化症 2 名

* Yoshinori IMANISHI 近畿大学東洋医学研究所

共同研究者 : Toshiyuki AKAMARU, Shigeru ARICHI 近畿 大学東洋医学研究所

Key Words : Thermal Video System, 少数穴, 腹部瘀血 証, 曲泉
（男 2 ），慢性関節リウマチ 2 名（女 2 ），慢性荤炎 1 名（女 1 ), 本態性高血圧症 1 名(女 1 ), 結節性 紅斑 1 名(女 1 ), 年秢26～65歳，対象は左下腹部 に疺血証を， $l$-Liv-8に握痛を認めない健常者。

2) 室温: $25.0^{\circ} \mathrm{C} \pm 1.0^{\circ} \mathrm{C}$, 湿度 : $61 \% \pm 1 \%$

3）刺置針部位と方法

刺置針部位は $l$ - Liv-8 (左曲線)

使用針は寸 3,5 番（針の直径 $0.24 \mathrm{~mm}$, 長さ $38 \mathrm{~mm}$ ) ステンレス製（医道の日本社製）で，管針 法により切皮し，直刺とし，迴旋術により針を進 め，雀啄を約10秒間加え，針のヒビキを確認した。 針の深さは1.0〜 $1.3 \mathrm{~cm}$ とした。

4）測定装置および測定方法

(1)熱電対式皮膚温度計（デンマーク・エラブ社 製) (温度分解能は $0.1^{\circ} \mathrm{C}$ )

患者を仰臥位とし，胸腹部の衣類を開き，20分 後, 刺置針前と後 1 分, 3 分, 5 分に患者では左 下腹部瘀血証部, 健常者では左下腹部〔 $l$-S -27 (左 大巨) (以下同じ)」の皮虐温の変化を測定した。更 に $l$-S-25(左天枢) , r-S-25 (右天枢) , CV-13(上 脘)部も測定した。

(2)Thermal Video System (Nippon Avionics, 
Co., Ltd. 製)

T V S の撮影はそのカメラヘッドにアルゴンガ スを注入し，赤外線検知器を泠却する。連動する プロセッサー，モニターTVを作動することによ つて熱画像を得た。

T V S は撮影部位が $1.5 \mathrm{~m}$ の距離に設定し，反 射率 $=0.95 \sim 1.0$, 温度分解能 (SENS) は $0.1^{\circ} \mathrm{C}$ と し, 最低温度は $29.0^{\circ} \mathrm{C}$ とた。

患者を仰臥位とし，胸腹部の衣類を開き，20分 後, 刺置針前と後 3 分に皮膚温の測定を行った。 （図 1 )

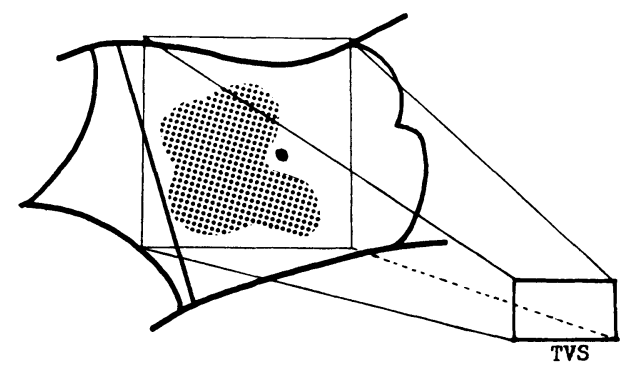

Fig. 1 患者は仰臥位

\section{III 実験 結 果}

\section{1）熱電対式皮膚温度計による実験}

コントロールの健常者は $l$-Liv-8に刺置針を行 い, 左下腹部の皮虐温は刺置針前に比し， 1 分， 3 分, 5 分後では何ら変化はみられなかった。(表 1 )

左下腹部に疮血証を認め, $l-\mathrm{Liv}^{-} 8$ に圧痛のあ る患者群の $l$-Liv-8に刺置針を行うと, 左下腹部
瘀血証部皮膚温は健常者群の左下腹部に同様処置 した場合の左下腹部皮膚温に比し， 5 分後に 0.2 $\pm 0.1^{\circ} \mathrm{C}$ 有意 $(\mathrm{P}<0.001)$ の上昇が認められた。 $l$-S-25, r-S-25，CV-13では刺置針前と後の皮膚 温の変動に有意差は認められなかった。(表 2,3， 4 )

また，健常者はCV-13 部皮膚温は $l$-Liv-8の刺 置針前と 5 分後では有意差はみられなかったが, 患者では左下腹部疙血証部皮虙温の上昇は C V 13部皮膚温の変動に対して有意差を認めた。

2) Thermal Video System による実験

〔症例 1 〕 心身症, K. W. 33歳, 女性

初 診：昭和 58 年 10 月 5 日

主 訴：前頭部痛, 両側頭部痛

既往症：出産 1 回

現病歴：約 4 年前から頭痛, 頭重感，のぼせ, めまい, 肩こり, 軽い腰痛がおこり下腹部および 下肢が冷えるようになった。心身症といわれ治療 したが，治らないまま今日に至った。最近不眠が 加わってきた。夜間排尿 2 回，大便 $2 \sim 3$ 日に 1 回。

現 症：体格やや大(陽，実)，舌，苔 $(-)$ や 暗赤色, 裏うっ血 $(+)$, 脈, 沈, 小, 左下腹部, 抵抗 $(+)$, 圧痛 $(+⿻$ 卅), 皮膚および皮下組織握痛 $(\pi)$, 右下腹部, 抵抗 $(+)$, 圧痛 $(\#)$, 皮膚扮よ び皮下組織握痛 $(\#), \quad l$ - Liv-8, 握痛 $(+), l$-Sp10 (左血海), 圧痛 $(+), \mathrm{r}-\mathrm{LI}-4$ (右合谷), 握痛 $(+)$ 。

血液検査：表 5 の通り著変なし。

〔症例 1 の実験結果〕

1）左下腹部疮血証部の皮虐温は腹部の他部に比

Table 1 健常者群の $\ell$-Liv-8 刺置針前 ( 0 分) と後の皮属温

\begin{tabular}{c|c|c|c|c}
\hline \hline & \multicolumn{4}{|c}{ Control $(\mathrm{n}=6)$} \\
\hline \multirow{2}{*}{ time $(\mathrm{m})$} & $\mathrm{A}$ & $\mathrm{B}$ & $\mathrm{C}$ & $\mathrm{D}$ \\
\hline 0 & $33.4 \pm 1.10$ & $33.6 \pm 1.06$ & $33.6 \pm 1.06$ & $33.7 \pm 1.03$ \\
\hline 1 & $33.4 \pm 1.10$ & $33.6 \pm 1.06$ & $33.6 \pm 1.06$ & $33.7 \pm 1.03$ \\
3 & $33.4 \pm 1.10$ & $33.6 \pm 1.06$ & $33.6 \pm 1.06$ & $33.7 \pm 1.03$ \\
5 & $33.4 \pm 1.10$ & $33.6 \pm 1.06$ & $33.6 \pm 1.06$ & $33.7 \pm 1.03$ \\
\hline 上昇温度 & $0.0 \pm 0$ & $0.0 \pm 0$ & $0.0 \pm 0$ & $0.0 \pm 0$ \\
\hline \hline
\end{tabular}

$\mathrm{A}: l-\mathrm{S}-27$ (左大巨) $\mathrm{B}: l-\mathrm{S}-25$ (左天枢) $\mathrm{C}: \mathrm{r}-\mathrm{S}-25$ (右天枢) $\mathrm{D}: \mathrm{CV}-13$ (上脘) 
Table 2 患者群の $\ell$-Liv-8 刺置針前( 0 分) と後の皮庙温

\begin{tabular}{c|c|c|c|c|c|c|c|c|c|c|c|c}
\hline \hline $\begin{array}{c}\text { Old Sex } \\
\text { Disease }\end{array}$ & \multicolumn{3}{|c|}{ R. A. 26 F UCS } & \multicolumn{4}{c|}{ O. N. 62 M } & \multicolumn{4}{c|}{ Y. M. 34 F UCS } \\
\hline time $(\mathrm{m})$ & A & B & C & D & A & B & C & D & A & B & C & D \\
\hline 0 & 31.2 & 32.2 & - & 32.2 & 30.6 & 31.2 & - & 34.0 & 32.9 & 32.9 & 34.2 & 34.2 \\
\hline 1 & 31.2 & - & - & - & 30.6 & - & - & - & 32.9 & - & - & - \\
3 & 31.2 & - & - & - & 30.8 & - & - & - & 32.9 & - & - & - \\
5 & 31.4 & 32.0 & - & 32.0 & 31.0 & - & - & - & 33.0 & - & - & - \\
\hline 上昇温度 & 0.2 & -0.2 & - & -0.2 & 0.4 & - & - & - & 0.1 & - & - & - \\
\hline \hline
\end{tabular}

\begin{tabular}{c|c|c|c|c|c|c|c|c|c|c|c|c}
\hline \hline $\begin{array}{c}\text { Old Sex } \\
\text { Disease }\end{array}$ & \multicolumn{3}{|c|}{ M. T. 29F. UCS } & \multicolumn{4}{c|}{ J. W. 51 F R. A. } & \multicolumn{4}{c}{ S. M. 52 F UCS } \\
\hline time(m) & A & B & C & D & A & B & C & D & A & B & C & D \\
\hline 0 & 31.2 & 31.0 & 30.6 & 31.0 & 32.2 & 31.2 & 31.8 & 32.6 & 34.2 & 33.4 & 33.0 & 34.1 \\
\hline 1 & 31.2 & - & - & - & 32.2 & 31.2 & 31.8 & 32.4 & 34.2 & 33.4 & 33.0 & 34.1 \\
3 & 31.2 & - & - & - & 32.4 & 31.4 & 31.6 & 32.4 & 34.4 & 33.4 & 33.0 & 34.1 \\
5 & 31.3 & - & - & - & 32.4 & 31.4 & 31.6 & 32.4 & 34.4 & 33.6 & 33.2 & 34.1 \\
\hline 上昇温度 & 0.1 & - & - & - & 0.2 & 0.2 & -0.2 & -0.2 & 0.2 & 0.2 & 0.2 & 0 \\
\hline \hline
\end{tabular}

$\mathrm{A}$ ：左下腹部 $\mathrm{B}: l$-S-25(左天枢) $\mathrm{C}: \mathrm{r}$-S-25(右天枢) $\mathrm{D}: \mathrm{CV}-13$ (上脘) USC $:$ 心身症

Table 3 患者群の -Liv-8 刺置針 ( 0 分) と後の皮成温

\begin{tabular}{c|c|c|c|c|c|c|c|c|c|c|c|c}
\hline \hline $\begin{array}{c}\text { Old Sex } \\
\text { Disease }\end{array}$ & \multicolumn{4}{|c|}{ M. S. 50 F UCS } & \multicolumn{3}{c|}{ S. O. 63 F Ch. Hepa. } & \multicolumn{4}{c}{$\begin{array}{c}\text { H. T. 44 M } \\
\text { Arteriosclerosis }\end{array}$} \\
\hline time(m) & A & B & C & D & A & B & C & D & A & B & C & D \\
\hline 0 & 31.2 & 31.3 & 31.2 & 31.7 & 33.4 & 34.4 & 34.2 & 33.8 & 30.8 & 30.6 & 30.8 & 31.1 \\
\hline 1 & 31.2 & 31.3 & 31.2 & 31.7 & 33.5 & 34.4 & 34.2 & 33.8 & 30.8 & 30.6 & 30.8 & 31.1 \\
3 & 31.4 & 31.3 & 31.2 & 31.7 & 33.6 & 34.6 & 34.2 & 33.8 & 31.0 & 30.6 & 30.8 & 31.1 \\
5 & 31.4 & 31.3 & 31.4 & 32.0 & 33.7 & 34.6 & 34.2 & 33.8 & 31.2 & 30.6 & 30.8 & 31.1 \\
\hline 上昇温度 & 0.2 & 0 & 0.2 & 0.3 & 0.3 & 0.2 & 0 & 0 & 0.4 & 0 & 0 & 0 \\
\hline \hline
\end{tabular}

\begin{tabular}{c|c|c|c|c|c|c|c|c|c|c|c|c}
\hline \hline $\begin{array}{c}\text { Old Sex } \\
\text { Disease }\end{array}$ & \multicolumn{3}{|c|}{ H. A. 48 M Ch. Hepa. } & \multicolumn{4}{c|}{ T. Y. 49 F UCS } & \multicolumn{4}{|c}{ T. M. 60 F } \\
Erytheme Noueux \\
\hline time $(\mathrm{m})$ & $\mathrm{A}$ & $\mathrm{B}$ & $\mathrm{C}$ & $\mathrm{D}$ & $\mathrm{A}$ & $\mathrm{B}$ & $\mathrm{C}$ & $\mathrm{D}$ & $\mathrm{A}$ & $\mathrm{B}$ & $\mathrm{C}$ & $\mathrm{D}$ \\
\hline 0 & 33.8 & 32.9 & 34.6 & 34.4 & 30.4 & 31.0 & 31.6 & 32.2 & 32.0 & 31.6 & 32.2 & 33.0 \\
\hline 1 & 33.8 & 32.9 & 34.6 & 34.4 & 31.0 & 31.0 & 31.6 & 32.2 & 32.0 & 31.6 & 32.2 & 33.0 \\
3 & 34.0 & 32.9 & 34.6 & 34.4 & 31.4 & 31.2 & 31.6 & 32.2 & 32.0 & 31.6 & 32.2 & 33.0 \\
5 & 34.0 & 32.9 & 34.6 & 34.4 & 31.6 & 31.2 & 31.6 & 32.2 & 32.2 & 31.6 & 32.2 & 33.0 \\
\hline 上昇温度 & 0.2 & 0 & 0 & 0 & 1.2 & 0.2 & 0 & 0 & 0.2 & 0. & 0 & 0 \\
\hline \hline
\end{tabular}

$\mathrm{A}$ ：左下腹部 $\mathrm{B}: l-\mathrm{S}-25$ (左天枢) $\mathrm{C}: \mathrm{r}-\mathrm{S}-25$ (右天枢) $\mathrm{D}: \mathrm{CV}-13$ (上脘) UCS : 心身症 
Table 4 患者群の -Liv-8 刺置針前 ( 0 分) と後の皮庙温

\begin{tabular}{c|c|c|c|c|c|c|c|c|c|c|c|c}
\hline \hline $\begin{array}{c}\text { Old Sex } \\
\text { Disease }\end{array}$ & \multicolumn{4}{|c|}{ H. M. 36F. R. A. } & \multicolumn{4}{c|}{ Y. K. 47 F } & \multicolumn{4}{c}{ T. H. 37 M UCS } \\
\hline time $(\mathrm{m})$ & $\mathrm{A}$ & $\mathrm{B}$ & $\mathrm{C}$ & $\mathrm{D}$ & $\mathrm{A}$ & $\mathrm{B}$ & $\mathrm{C}$ & $\mathrm{D}$ & $\mathrm{A}$ & $\mathrm{B}$ & $\mathrm{C}$ & $\mathrm{D}$ \\
\hline 0 & 33.4 & 33.2 & 33.0 & 33.9 & 33.8 & 33.0 & 32.6 & 34.0 & 32.6 & 32.6 & 32.8 & 32.6 \\
\hline 1 & 33.4 & 33.2 & 33.0 & 33.9 & 33.8 & 33.0 & 32.6 & 34.0 & 32.6 & 32.6 & 32.8 & 32.6 \\
3 & 33.7 & 33.2 & 33.0 & 33.9 & 33.9 & 33.1 & 32.6 & 34.0 & 32.6 & 32.6 & 32.8 & 32.6 \\
5 & 33.7 & 33.2 & 33.0 & 33.8 & 34.0 & 33.2 & 32.6 & 34.0 & 32.6 & 32.6 & 32.8 & 32.6 \\
\hline 上年温度 & 0.3 & 0 & 0 & -0.1 & 0.2 & 0.2 & 0 & 0 & 0 & 0 & 0 & 0 \\
\hline \hline
\end{tabular}

\begin{tabular}{c|c|c|c|c|c|c|c|c|c|c|c|c}
\hline \hline $\begin{array}{c}\text { Old Sex } \\
\text { Disease }\end{array}$ & \multicolumn{3}{|c|}{ H. H. 65 F Ch. Hepa. } & \multicolumn{4}{c|}{ H. K. 47 F UCS } & \multicolumn{3}{c}{ C. O. 65 F Hypertension } \\
\hline time $(\mathrm{m})$ & $\mathrm{A}$ & $\mathrm{B}$ & $\mathrm{C}$ & $\mathrm{D}$ & $\mathrm{A}$ & $\mathrm{B}$ & $\mathrm{C}$ & $\mathrm{D}$ & $\mathrm{A}$ & $\mathrm{B}$ & $\mathrm{C}$ & $\mathrm{D}$ \\
\hline 0 & 32.0 & 31.6 & 32.2 & 32.6 & 33.0 & 33.4 & 33.0 & 34.8 & 32.0 & 32.2 & 32.0 & 32.8 \\
\hline 1 & 32.0 & 31.6 & 32.2 & 32.6 & 33.0 & 33.4 & 33.0 & 34.8 & 32.0 & 32.2 & 32.0 & 32.8 \\
3 & 32.2 & 31.6 & 32.2 & 32.6 & 33.0 & 33.4 & 33.0 & 34.8 & 32.0 & 32.2 & 32.0 & 32.8 \\
5 & 32.2 & 31.6 & 32.2 & 32.6 & 33.2 & 33.4 & 33.0 & 34.8 & 32.0 & 32.2 & 32.0 & 32.8 \\
\hline 上昇温度 & 0.2 & 0 & 0 & 0 & 0.2 & 0 & 0 & 0 & 0 & 0 & 0 & 0 \\
\hline \hline
\end{tabular}

$\mathrm{A}$ ：左下腹部 $\mathrm{B}:$ : - S - 25 (左天枢) $\mathrm{C}: \mathrm{r}-\mathrm{S}-25$ (右天枢) D : CV-13(上脘) UCS : 心身症

Table 5 血液臨床検査

\begin{tabular}{lrlr}
\hline \hline WBC & $5.4 \times 10^{3}$ & Alk. Phos. & $46 \mathrm{U} / \mathrm{L}$ \\
RBC & $4.22 \times 10^{6}$ & A/G & 1.7 \\
Ht & $35.4 \%$ & LDH & $133 \mathrm{U} / \mathrm{L}$ \\
Hem & $12.1 \mathrm{~g} / \mathrm{dl}$ & $\mathrm{CPK}$ & $50 \mathrm{U} / \mathrm{L}$ \\
Glucose & $92 \mathrm{mg} / \mathrm{dl}$ & BUN & $13 \mathrm{mg} / \mathrm{dl}$ \\
Cholesterol & $155 \mathrm{mg} / \mathrm{dl}$ & Creatinine & $0.8 \mathrm{mg} / \mathrm{dl}$ \\
Triglycerides & $72 \mathrm{mg} / \mathrm{dl}$ & Uric Acid & $4.5 \mathrm{mg} / \mathrm{dl}$ \\
T. Protein & $7.5 \mathrm{~g} / \mathrm{dl}$ & $\mathrm{Na}$ & $144 \mathrm{mEq} / 1$ \\
Albumin & $4.7 \mathrm{~g} / \mathrm{dl}$ & $\mathrm{K}$ & $3.7 \mathrm{mEq} / 1$ \\
T. Bilirubin & $0.5 \mathrm{mg} / \mathrm{dl}$ & $\mathrm{Cl}$ & $108 \mathrm{mEq} / 1$ \\
D. Bilirubin & $0.1 \mathrm{mg} / \mathrm{dl}$ & Inorganic P & $3.6 \mathrm{mg} / \mathrm{dl}$ \\
GOT & $22 \mathrm{U} / \mathrm{L}$ & $\mathrm{Ca}$ & $9.4 \mathrm{mg} / \mathrm{dl}$ \\
GPT & $13 \mathrm{U} / \mathrm{L}$ & $\mathrm{Ca} / \mathrm{P}$ & 2.6 \\
\hline \hline
\end{tabular}

し低温を示した。(図 2 )

2） $l$-Liv-8 に刺置針 3 分後では左下腹部瘀血証 部の皮膚温の上昇がみられ，左下腹部の低温の 範囲が縮小した。(図 3 )
〔症例 2〕 心身症, S.K. 34歳, 女性 初 診：昭和58年 9 月 19 日 主 訴: 頭重感, 肩こり

既往症：出産 1 回, 流産 1 回, 前年 9 月両側卵 


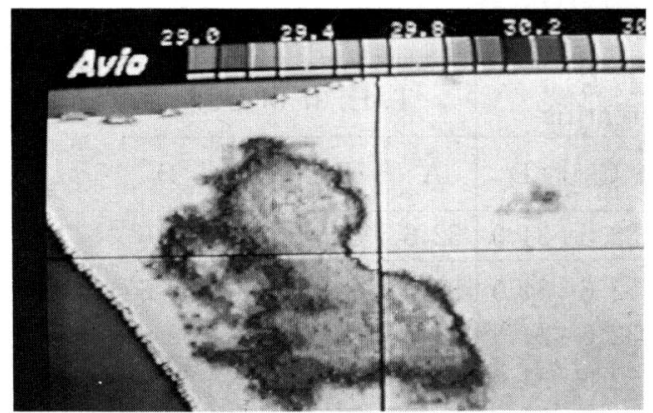

Fig. 2 症例1. $\ell$-Liv-8 刺置針前

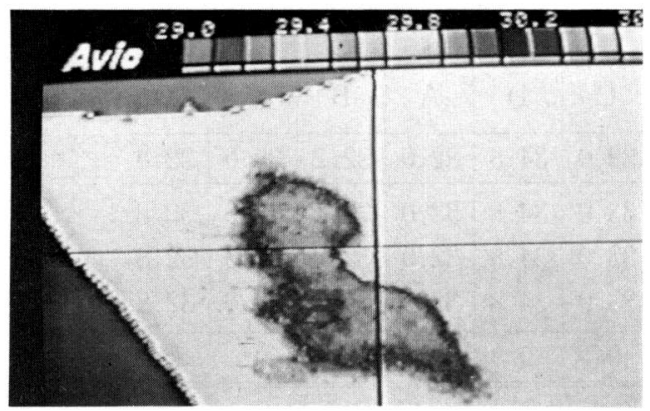

Fig. 3 症例1. $\ell$-Liv-8 刺置針 3 分後

巣囊腫にて手術。

現病歴：3 年前から心身症と診断され現在まで 治療しているが軽快しない。

現 症: 体格中等度(除, 虚), 皮䖉, つやがな い, 舌, 苔 $(-)$, やや暗赤色, 裏うつ血 $(+)$, 脈, 沈, 小, 左下腹部, 抵抗 $(+)$, 圧痛 $(+\pi)$, 皮䖉扮 よび皮下組織握痛 $(+), l-L i v-8$, 握痛 $(+), l-\mathrm{Sp}$ -10 , 圧痛 $(+), \quad \mathrm{r}-\mathrm{LI}-4$, 握痛 $(+), \quad l-\mathrm{SI}-11$ (左 天宗), 压痛( H)。

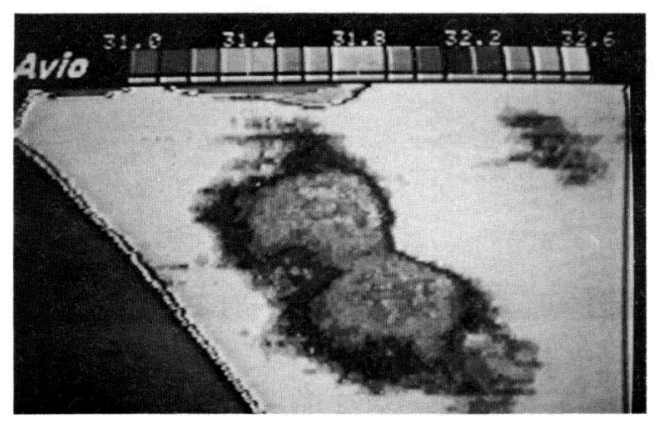

Fig. 4 症例2. $\ell$-Liv-8 刺置針前

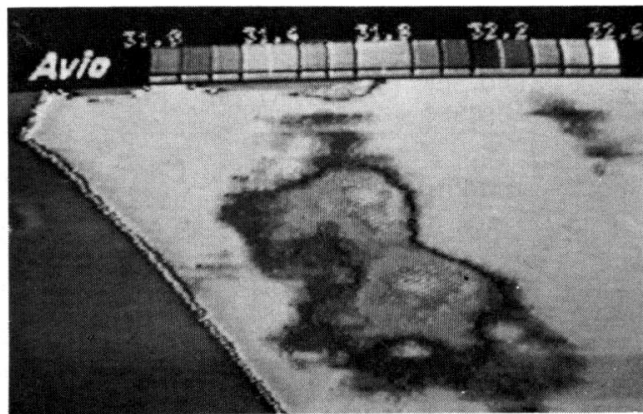

Fig. 5 症例2. $\ell$-Liv-8刺置針 3 分後

[症例 2 の実験結果]

1) 左下腹部瘀血証部の皮虐温は腹部の他部に比 し低温を示した。(図4)

2) $l$ - Liv-8に刺置針 3 分後では左下腹部瘀血証 部の皮膚温の上昇がみられ，左下腹部の低温の 範囲が縮小した。(図 5 )

\section{IV 考察}

『傷寒論』に「小腹急結する者は苟ち之を攻むべ し，桃核承気湯宜し」と述べてあり，また『腹證 奇覽』には「小腹に急結ありて上衝し, 悪血深し」 と記載されている゙。

有地は腹部瘀血証のある心身症が多く，女性心 身症では $l$-Liv-8 と r-LI-4に握痛を, r-LI-11(右 曲池）と $l-\mathrm{SI}-11$ に圧痛を認めることが多いと述べ た ${ }^{3}$ 。

『霊枢, 劂病篇』に「下血する病は曲泉に針せよ」 および『同書，経筋篇』に「痛む所に針せよ」と 記載されている゙!。

以上は肝経の $\mathrm{Liv}^{-} 8$ が瘀血に関係した経穴であ リ，「これに針せよ」という本治法を述べたもので ある。

左下腹部瘀血証部( 小腹急結)の皮䖉温は腹部の 他部に比し低温を示した。 $l$ - Liv-8 に刺置針する と左下腹部瘀血証部の皮䖉温は上昇し, CV - 13 部 の皮覤温の変動に対し有意差を認めた。これは, $l$ - Liv-8 と左下腹部の瘀血証部と関連があり, CV13部とは関連のないことを示している。

健常者では $l$ - Liv-8の刺置針で左下腹部皮膚温 の上昇は認められなかった。これは刺置針に使用 する経穴の関連部位が正常では刺置針によって変 
化しないことを示し，針の正常化作用を示したこ とになる。

TVS でも $l$ - Liv-8への刺置針により左下腹部 瘀血証部の皮膚温の上昇を認め, 低温部の範囲の 縮小を認めた。

有地は瘀血の腹証は間葉系免疫炎症を推定して いるが ${ }^{5)}$ 針の作用は間葉系代謝伝達作用ともいう べきホメオスターティックな作用もあると述べて いる1'。

この実験は針の遠隔効果を客観的に示したもの である。

\section{$\mathrm{V}$ 結 論}

左下腹部瘀血証に対し，皮膚温度計による皮虐 温の測定と T V Sによる皮膚温の変動観察により 次の結果を得た。

1）左下腹部瘀血証部の皮膚温は腹部の他の部位 より低温を示す。

2）握痛のある $l$-Liv-8への 3 分， 5 分間の刺置 針で左下腹部瘀血証部の皮膚温は有意に上昇し た。またT V S で検すると低温部の範囲は縮小 した。

3）同上の処置により左下腹部瘀血証部皮膚温の 上昇は CV-13 部皮膚温の変動にに比して有意 差を示した。

4) 健常者では同様の処置では左下腹部の皮膚温 の上昇は認められなかった。

5）針の作用の一つは遠隔異常部の正常化であり, 正常部には無効であることが明になり，遠隔部 位への効果を客観的に証明出来た。

\section{引用文献}

1）有地滋：銊炎の作用機序に関する研究，日鐵炎 誌 $27(2) ; 97 \sim 107 .(1978)$

2) 稲葉文礼, 和久田叔虎 : 腹證奇覧, 腹證奇覧翼 (1), 近世漢方医学書集成, 83 , 名著出版, 東京 (1982), p.266.

3) S. Arichi, et, al : Clinical Observations on Several Meridian Loci in Chronic Hepatitis and Livercirrhosis in Comparison with Those in Female Neurovegetative Disorder, Pregnancy, and the Steroid Side-effects Syndrome, American Journal of Chinese Medicine $7 ; 157 \sim 170$. (1979)

4) 霊枢：意釋霊枢経, 小曽戸丈夫著, 東洋医学研 究会九州㤅話会, 久留米(1969), p.58, 41 42.

5) 有地滋: 瘀血の免疫遺伝学的考察, 瘀血研究, 第 1 回瘀血総合科学研究会講演記録集, 瘀血総 合科学研究会編, 自然社, 東京(1982), p.73. (干589 大阪府南河内郡狭山町西山380 近畿大学東洋医学研究所) 


\section{Acupunctural Effect of a Single Stationary Insertion}

1. Acupunctural effect on the (Congested-Blood (Tenderness) Syndrome in the Left Hypogastric Region), Demonstrated by Means of a Thermal-Video System.

\section{Yoshinori Imanishi, Toshiyuki Akamaru and Shigeru Arichi}

The Research Institute of Oriental Medicine, Kinki University

To demonstrate acupunctural effects on remote areas of the human body, a needle was held stationary at 1-Lv-8 and the changes in skin temperature were measured at the location of the congested-blood syndrome in the left hypogastric region, using a skin thermometer and a thermal video system. The acupuncture caused the temperature to rise from a level lower than in the normal state. As a control, healthy persons were treated in the same manner, but no appreciable change was observed.

With a patient having congested-blood syndrom in the left hypogastric region, the 1-Lv-8 point was tender to the touch. This was not the case with healthy persons.

It has thus been demonstrated that a stationary insertion at an abnormal point has an effect on the specific, remote location where the abnormal condition exists.

Only one insertion at an abnormal point has proven effective. 